Editorial

\title{
International Archives of Otorhinolaryngology: 20 Years of Excellence!
}

\author{
Ricardo Ferreira Bento, MD, PhD ${ }^{1}$ \\ 1 Professor and Chairman of Otolaryngology Department, School of \\ Medicine, University of São Paulo (FMUSP), São Paulo, SP, Brazil \\ Int Arch Otorhinolaryngol 2017;21:1-3.
}

International Archives of Otorhinolaryngology (IAO) celebrates the $20^{\text {th }}$ anniversary of continued publication. Founded in $1997,{ }^{1}$ the journal has been supported by the Otorhinolaryngology Foundation for the publication of experimental and clinical scientific articles in the fields of otorhinolaryngology, head and neck surgery, speech therapy, audiology, and related sciences.

Founded at the beginning of the Internet age, it was the world's first electronic journal to be published in both printed and online versions. ${ }^{2,3}$ Because it seemed like a Science Fiction project at the time, many thought it would not succeed! The journal was originally conceived by Dr. Claudio Lazzarini, an otorhinolaryngologist at Hospital das Clínicas, FMUSP. Since he was an enthusiast and pioneer in the field of computers, software, and this new means of communication "the Internet," the journal was named @rquivos da Fundação Otorrinolaringologia. The “@” symbol replaced the letter "A" since it was available online.

The journal originated in academia at the Universidade de São Paulo, thus, it was rooted in the scientific spirit. The publication is not intended to be used for commercial purposes, and publishing has always been funded by a nonprofit organization.

I was awarded the privilege of being its first editor-in-chief, followed by Professor Tanit Ganz Sanchez (1999-2005), ${ }^{3}$ Marcelo Miguel Hueb (2006-2008), ${ }^{4}$ and Geraldo Pereira Jotz ${ }^{5}$ since 2009. Aline Bittencourt has been a co-editor since 2013.

Excellence is sought in terms of original articles, systematic reviews, and case reports for publication in the journal; additionally, the content of these must contribute to the body of scientific knowledge in the field of otorhinolaryngology. In 2002, the journal was renamed @rquivos de Otorrinolaringologia. ${ }^{6}$ In 2003, Lilacs and Lilacs-Express-Latin American and Caribbean Center on Health Sciences Information ${ }^{7}$ indexed it, which was a first step toward internationalization.

In 2004, the Latindex (i.e., Regional Cooperative Online Information System for Scholarly Journals from Latin America, the Caribbean, Spain, and Portugal) indexed the journal. ${ }^{8}$ In 2006, it was renamed @rquivos Internationais de Otorrinolaringologia. ${ }^{4}$ At the same time, the Directory of Open Access Journals (DOAJ) indexed it, ${ }^{9,10}$ and it became an open and universal access journal (no subscription required), since science should be available for all. In the meantime, the Foundation for Science Research of Ribeirão Preto (FUNPEC-RP) also indexed it. ${ }^{11}$

In 2010, already fully internationalized, it was determined that articles appearing in the journal should be published in English only, following the global trend in which English was regarded as the lingua franca in science because it enabled broader visibility and impact. It was renamed International Archives of Otorhinolaryngology, and the Scientific Electronic Library Online (SciELO) indexed it. ${ }^{12}$

In 2011, 2012, and 2013, Scopus, ${ }^{13}$ PubMed, PubMed Central (PMC), ${ }^{14}$ and Embase, ${ }^{15}$ respectively, indexed the journal, and it reached its pinnacle.

Currently, the journal has reached a level of citations to be officially indexed by International Scientific Indexing (ISI), as it is about to achieve the h-index necessary for this action.

Until 2013, H Máxima Editora edited the journal; since then, Thieme Medical Publishers, a leading international publisher, ${ }^{16}$ has performed this service.

The journal is currently available online (open access) and in a printed version for subscribers.

The data below show the importance of IAO over the past 20 years (-Tables 1 and 2). Authors from over 30 countries

Table 1 Publications history (1997-2016)

\begin{tabular}{|l|l|}
\hline Editions & Number \\
\hline Volumes & 20 \\
\hline Issues & 80 \\
\hline Supplements & 7 \\
\hline Documents & 3,384 \\
\hline
\end{tabular}

have applied for publication (-Fig. 1).

We are grateful for the collaboration of a highly skilled Editorial Review Board and Peer Review Board.
Address for correspondence Ricardo Ferreira Bento, MD, PhD, DOI http://dx.doi.org/ 10.1055/s-0036-1596039. Department of Otorhinolaryngology, ISSN 1809-9777. Universidade de São Paulo, Av.

Dr. Enéas de Carvalho Aguiar 255,

$6^{\circ}$ andar, sala 6167, São Paulo,

SP 05403-000, Brazil

(e-mail: rbento@gmail.com).
Copyright $\odot 2017$ by Thieme-Revinter Publicações Ltda, Rio de Janeiro, Brazil

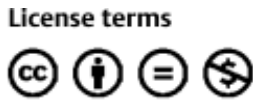


Table 2 History of published articles (1997-2016)

\begin{tabular}{|l|l|l|}
\hline Document type & Documents & Definition \\
\hline Article & 874 & $\begin{array}{l}\text { Original research or opinion. However, case reports, technical and research notes and } \\
\text { short communications are also considered to be articles. }\end{array}$ \\
\hline Review & 150 & $\begin{array}{l}\text { Significant review of original research. Educational items that review specific issues within } \\
\text { the literature are also considered to be reviews. }\end{array}$ \\
\hline Article in Press & 40 & Accepted article made available online before official publication. \\
\hline Editorial & 71 & Summary of several articles or provides editorial opinions or news. \\
\hline Erratum & 1 & Report of an error, correction or retraction of a previously published paper. \\
\hline Letter & 1 & Letter to or correspondence with the editor. \\
\hline Note & 7 & Note, discussion, or commentary. \\
\hline $\begin{array}{l}\text { Conference } \\
\text { meeting abstracts }\end{array}$ & 2240 & $\begin{array}{l}\text { Proceedings can be published as serial or non-serial, and may contain either the full } \\
\text { articles of the papers presented or only the abstracts. }\end{array}$ \\
\hline
\end{tabular}

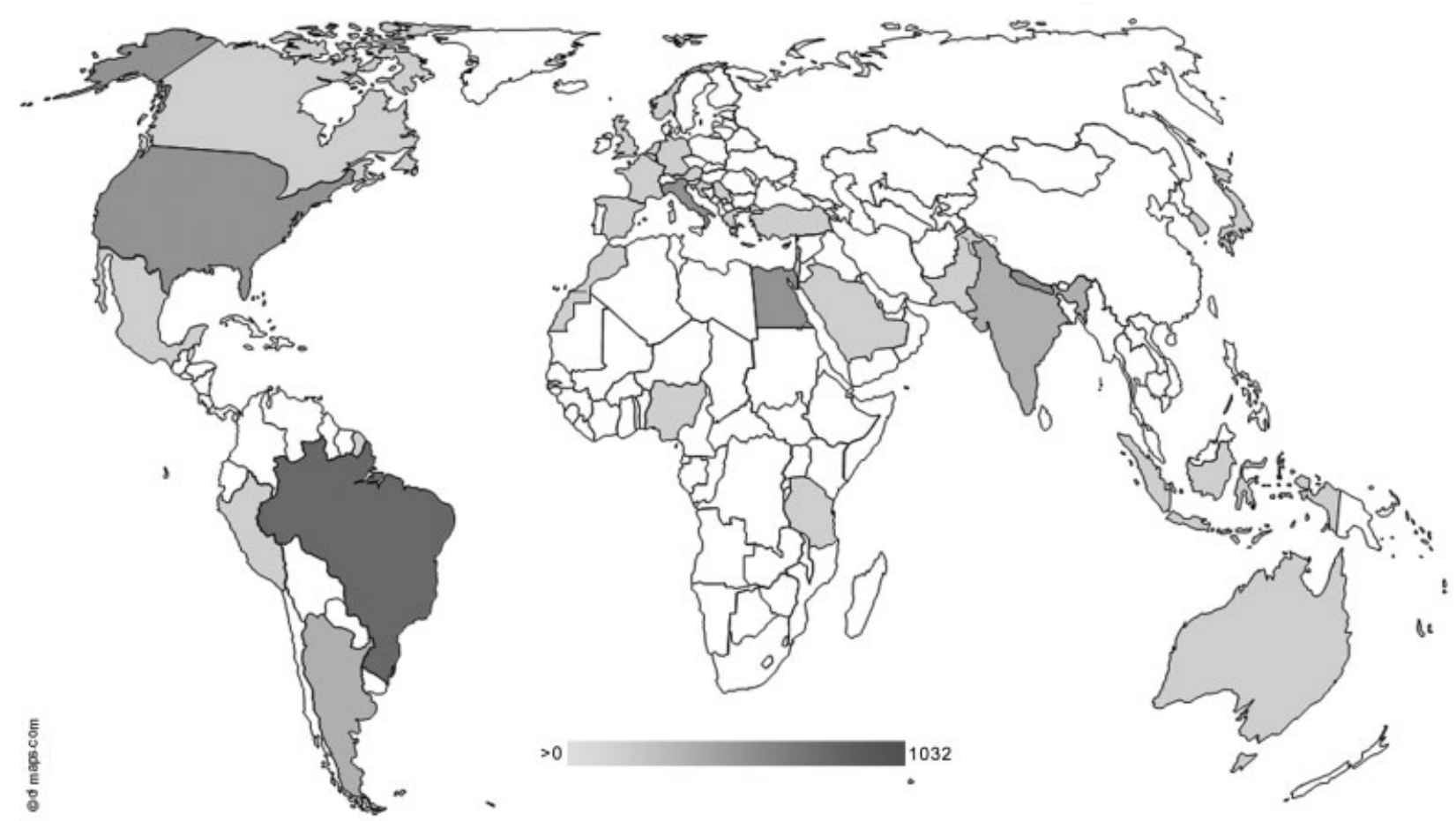

Fig. 1 Distribution of articles published by authors from 33 countries.

Geraldo Jotz, the editor-in-chief, and Aline Bittencourt, the co-editor, perform their jobs exceptionally.

Adilson Montefusco, our librarian, participates in journal publishing and publication support.

Enjoy the IAO, an academic journal.

Ricardo Ferreira Bento

\section{References}

1 Miniti A, Bento RF. Editorial. Arq Fund Otorrinolaringol 1997;1(1):1

2 Sanchez TG, Mion O, Bento RF, Miniti A. Editorial. Arq Otorrinolaringol 2005;9(3):172
3 Sanchez TG. Uma despedida alegre, com a sensação de missão cumprida. Arq Otorrinolaringol 2005;9(4):256

4 Hueb MM. Editorial. Arq Int Otorrinolaringol 2006;10(1):4

5 Jotz GP. Editorial. Arq Int Otorrinolaringol 2009;13(1):5

6 Sanchez TG, Mion O, Bento RF, Miniti A. Editorial. Arq Otorrinolaringol 2002;6(1):4

7 Sanchez TG, Mion O, Bento RF, Miniti A. Editorial. Arq Otorrinolaringol 2003;7(1):4

8 Sanchez TG, Mion O, Bento RF, Miniti A. Editorial. Arq Otorrinolaringol 2004;8(4):256

9 Hueb MM. Editorial. Arq Int Otorrinolaringol 2008;12(4):480

10 DOAJ - Directory of Open Access Journals. [cited 2016 Oct 20]. Available from: https://doaj.org/ 
11 FUNPEC-RP - Fundação de Pesquisas Científicas de Ribeirão Preto. Sumários.org [cited 2016 Oct 20]. Available from: http://www. sumarios.org/

12 SciELO. International Archives of Otorhinolaryngology [cited 2016 Oct 19]. Available from: http://www.scielo.br/iao

13 Elsevier. Scopus [cited 2016 Oct 19]. Available from: https://www. scopus.com/

14 National Center for Biotechnology Information, U.S. National Library of Medicine. International Archives of Otorhinolaryngolo- gy: PubMed Central; [cited 2016 Oct 19]. Available from: https:// www.ncbi.nlm.nih.gov/pmc/journals/2661/

15 Elsevier. Embase [cited 2016 Oct 21]. Available from: https:// www.embase.com

16 Jotz GP, Bittencourt A. International archives of otorhinolaryngology and thieme medical publishers. Int Arch Otorhinolaryngol 2013;17(3):236 